\title{
ANALISIS PENERAPAN AKUNTANSI FORENSIK DAN AUDIT INVESTIGATIF TERHADAP PENCEGAHAN DAN PENGUNGKAPAN FRAUD DALAM PENGELOLAAN KEUANGAN DAERAH PADA PERWAKILAN BPKP PROVINSI SULAWESI UTARA
}

\author{
Recky Vincent Oktaviano Wuysang \\ Grace Nangoi \\ Winston Pontoh
}

\author{
Fakultas Ekonomi dan Bisnis, Universitas Sam Ratulangi Manado \\ (e-mail : reckyvow@gmail.com)
}

\begin{abstract}
The purpose of this study is to explore and analyze: (1) the implementation of forensic accounting is applicable and effective functioning of the fraud prevention (preventive); (2) the implementation of forensic accounting is applicable and effective functioning of the fraud detection (detective); and (3) the implementation of investigative audit applicable and effective functioning of the fraud investigation (repressive) in the local financial management.

The analytical method used is descriptive qualitative methods that examines the participants perspective and some informations from the key informan through in-depth interviews and additional questions instrument by using purposive sampling, then make data triangulation obtained sources and collection techniques for analysis interactively by reducing, displaying in the form of a narrative texts, tables, matrix, charts, and then drawn a conclusion.

The results of research and analysis states that forensic accounting is applicable and effective function to be applied to the fraud prevention (preventive) in the local financial management through the FCP, SPIP and SIMDA; forensic accounting is also applicable and effective function to be applied to the fraud detection (detective) in the local financial management through Operational Audit, Audit of Government goods and services Procurement (Probity Audit), EDP Audit: Computer Forensic, and Whistleblowers System; and the Audit Investigative very applicable and effective function to be applied to the fraud investigation (repressive) in the local financial management through investigative audits, in order to calculate losses of the state financial audits, and the provision of expert witness.
\end{abstract}

Keywords : Fraud, Forensic Accounting, Investigative Audit, Local Financial Management.

\subsection{Latar Belakang}

\section{PENDAHULUAN}

Praktik-praktik kecurangan (fraud) secara umum dan korupsi pada khususnya sampai sekarang ini masih terus menjadi isu fenomenal yang selalu menarik untuk dibahas. Berdasarkan data empirik selang beberapa tahun terakhir, Pemerintah Daerah dengan sektor keuangan daerah menjadi lembaga yang memiliki tingkat fraud (korupsi) paling dominan. Lewat peran dan kinerja dari BPKP selaku lembaga yang memiliki kewenangan untuk melakukan pengawasan keuangan bagi pemerintah pusat maupun pemerintah daerah, diharapkan dapat mampu menekan/meminimalisir berbagai tindakan fraud dengan melakukan pencegahan, pendeteksian dini, serta penindakan atas praktik-praktik fraud yang terjadi. Belakangan ini, perkembangan ilmu akuntansi forensik dan audit investigatif menjadi harapan bagi para aparat penegak hukum baik Kepolisian dan Kejaksaan maupun BPKP selaku APIP dalam upaya pencegahan maupun pengungkapan praktik-praktik fraud (korupsi). Oleh karena itu, perlu adanya penelitian-penelitian yang mengeksplorasi tentang penerapan akuntansi forensik dan audit investigatif dalam aplikasi dan keefektifan fungsinya terhadap pencegahan maupun pengungkapan fraud. 
Berdasarkan pokok-pokok masalah mengenai akuntansi forensik dan audit investigatif terhadap pencegahan dan pengungkapan fraud diatas, maka rumusan masalah dalam penelitian ini adalah sebagai berikut.

1. Bagaimana penerapan Akuntansi Forensik terhadap Pencegahan (preventif) fraud dalam pengelolaan keuangan daerah di Sulawesi Utara?

2. Bagaimana penerapan Akuntansi Forensik terhadap Pendeteksian (detektif) fraud dalam pengelolaan keuangan daerah di Sulawesi Utara?

3. Bagaimana penerapan Audit Investigatif terhadap Penanganan (represif) fraud dalam pengelolaan keuangan daerah di Sulawesi Utara?

\subsection{Tujuan Penelitian}

Berdasarkan latar belakang dan perumusan masalah diatas, maka tujuan yang ingin dicapai dalam penelitian ini adalah sebagai berikut.

1. Untuk mengekplorasi dan menganalisis aplikasi dan keefektifan penerapan Akuntansi forensik terhadap pencegahan (preventif) fraud dalam pengelolaan keuangan daerah di Sulawesi Utara.

2. Untuk mengekplorasi dan menganalisis aplikasi dan keefektifan penerapan Akuntansi forensik terhadap pendeteksian (detektif) fraud dalam pengelolaan keuangan daerah di Sulawesi Utara.

3. Untuk mengekplorasi dan menganalis aplikasi serta keefektifan penerapan Audit Investigatif terhadap penanganan (represif) fraud dalam pengelolaan keuangan daerah di Sulawesi Utara.

\subsection{Landasan Teori}

\section{TINJAUAN PUSTAKA}

\subsubsection{Strain Theory (Means - Ends Scheme)}

Robert K. Merton (1957) mengemukakan teorinya bahwa korupsi merupakan suatu perilaku manusia yang diakibatkan oleh tekanan sosial, sehingga menyebabkan pelanggaran norma-norma. Setiap sistem sosial memiliki tujuan dan manusia berusaha untuk mencapainya melalui cara-cara (means) yang telah disepakati.Teori Strain (Means-Ends Scheme) dari Merton ini ditujukan untuk menjawab bagaimana kebudayaan terlalu menekankan sukses ekonomi tetapi membatasi kesempatan-kesempatan untuk mencapainya yang akan menyebabkan tingkat korupsi yang tinggi. Suatu kehidupan masyarakat yang mementingkan anggota keluarga sendiri (nepotisme) maupun kepentingan antar individu dan kelompok (kolusi), akan menyebabkan orang lain iri dan menyuburkan korupsi. Demikian pula orang akan mencari jalan di dalam mencapai struktur kekuasaan agar ia mendapatkan kesempatan untuk memperoleh apa yang diinginkannya. Hal ini dapat menjelaskan mengapa banyak negara berkembang jatuh ke dalam wabah korupsi.

\subsubsection{Fraud Triangle Theory}

Donald R. Cressey (1953), mengungkapkan konsep fraud yang dikenal dengan fraud triangle atau segi tiga fraud. Cressey menyatakan alasan seseorang melakukan fraud, yaitu karena disebabkan oleh adanya :

1. tekanan (pressure), untuk melakukan kecurangan lebih banyak tergantung pada skondisi individu, seperti sedang menghadapi masalah keuangan, kebiasaan buruk seseorang seperti berjudi dan peminum; tamak atau mempunyai harapan/ tujuan yang tidak realistik.

2. kesempatan (opportunity), menurut penelitian yang dilakukan oleh IIA Research Foundation tahun 1984, dengan urutan paling sering terjadi adalah: terlalu mempercayai bawahan; kelemahan prosedur otorisasi dan persetujuan manajemen; kurangnya penjelasan dalam informasi keuangan pribadi (kecurangan perbankan); tidak ada pemisahan antara pemberian wewenang dan penjagaan aset; tidak ada pengecekan independen terhadap kinerja; kurangnya perhatian terhadap uraian secara rinci (detail); tidak ada pemisahan antara 
pemegang aset dan fungsi pencatatan; tidak ada pemisahan tugas akuntansi; kurang jelasnya pemberian wewenang; departemen/bagian jarang diperiksa; pernyataan tidak ada benturan kepentingan tidak disyaratkan; dan dokumen dan pencatatan kurang memadai.

3. pembenaran (rationalization), terjadi dalam hal seseorang atau sekelompok orang membangun pembenaran atas kecurangan yang dilakukan. Pelaku fraud biasanya mencari alasan pembenaran bahwa apa yang dilakukannya bukan pencurian atau kecurangan.

\subsubsection{GONE Theory}

Teori yang juga membahas perilaku fraud dengan baik dikemukakan oleh Jack Bologne (1993). Teori ini dikenal sebagai GONE theory. Bologna dalam Soepardi (2006) menjelaskan faktor-faktor yang mendorong terjadinya kecurangan (fraud) meliputi:

1. greed (keserakahan), berkaitan dengan adanya perilaku serakah yang secara potensial ada di dalam diri setiap orang.

2. opportunity (kesempatan), berkaitan dengan keadaan organisasi atau instansi masyarakat yang sedemikian rupa sehingga terbuka kesempatan bagi seseorang untuk melakukan fraud terhadapnya.

3. needs (kebutuhan), berkaitan dengan faktor-faktor yang dibutuhkan oleh individu untuk menunjang hidupnya yang menurutnya wajar.

4. exposure (pengungkapan), berkaitan dengan tindakan atau konsekuensi yang akan dihadapi oleh pelaku fraud apabila pelaku ditemukan melakukan fraud.

\subsubsection{Fraud}

Dalam istilah sehari-hari fraud sering diberi nama yang berlainan, seperti pencurian, penyerobotan, pemerasan, pengisapan, penggelapan, pemalsuan, dan lain-lain. Sesuai dengan Pernyataan Standar Auditing (PSA) No. 70, Fraud diterjemahkan sebagai kecurangan, sedangkan error dan irregularities masing-masing diterjemahkan sebagai kekeliruan dan ketidakberesan sesuai PSA sebelumnya yaitu PSA No.32. Fraud dapat diklasifikasikan menjadi tiga macam menurut Association of Certified Fraud Examinations (ACFE) yaitu:

1. Kecurangan Laporan Keuangan (Financial Statement Fraud)

Fraud yang dilakukan oleh manajemen yaitu dalam bentuk salah saji material laporan keuangan yang merugikan investor dan kreditor yang bersifat finansial atau non finansial.

2. Penyalahgunaan Aset (Asset Misappropriation)

Penyalahgunaan aset dapat digolongkan ke dalam 'kecurangan kas' dan kecurangan atas persediaan dan aset lainnya, serta fraudulent disbursement.

3. Korupsi (Corruption)

Korupsi terjadi apabila memenuhi tiga kriteria yang merupakan syarat bahwa seseorang bisa dijerat undang-undang korupsi, yaitu: 1) melawan hukum, 2) memperkaya diri sendiri atau orang lain atau korporasi, 3) merugikan keuangan negara atau perekonomian negara.

\subsubsection{Akuntansi Forensik}

Tuanakotta (2012) mengemukakan bahwa akuntansi forensik adalah penerapan disiplin akuntansi dalam arti luas, termasuk auditing, pada masalah hukum untuk penyelesaian hukum di dalam atau di luar pengadilan. Akuntansi forensik dapat diterapkan di sektor publik maupun swasta, sehingga apabila memasukkan pihak yang berbeda, maka akuntansi forensik menurut Crumbley dalam Tuanakotta (2012) mengemukakan bahwa secara sederhana akuntansi forensik dapat dikatakan sebagai akuntansi yang akurat untuk tujuan hukum, yang tahan uji dalam kancah perseteruan selama proses pengadilan, dalam proses peninjauan yudisial atau tinjauan administratif.

Bologna dan Lindquisdt (1995) mendefinisikan akuntansi forensik dan investigasi adalah aplikasi kecakapan finansial dan sebuah mentalitas penyelidikan terhadap isu-isu yang tidak terpecahkan, yang dijalankan dalam konteks aturan pembuktian. De Lorenzo (1993) mendefinisikan akuntansi forensik sebagai penerapan pengetahuan akuntansi dan keterampilan untuk masalah 
hukum, meskipun dalam lingkungan komersial yang kompleks saat ini makna dan penggunaan istilah ini jauh lebih luas.

Tuanakotta (2012) mengemukakan di sektor publik (pemerintahan), tahap-tahap dalam seluruh rangkaian akuntansi forensik terbagi-bagi diantara berbagai lembaga. Ada lembaga yang melakukan pemeriksaan keuangan negara (BPK), ada lembaga yang merupakan bagian dari pengawasan internal pemerintah (BPKP), ada lembaga-lembaga pengadilan, ada lembaga yang menunjang kegiatan memerangi kejahatan pada umumnya, dan korupsi khususnya (PPATK), dan lembaga-lembaga lainnya seperti KPK. Juga ada lembaga swadaya masyarakat yang berfungsi sebagai pressure group seperti ICW, Pekat UGM, dan sebagainya.

Di sektor publik maupun privat, akuntansi forensik berurusan dengan kerugian. Di sektor publik ada kerugian negara dan kerugian keuangan negara sedangkan di sektor privat juga ada kerugian yang timbul karena cidera janji dalam suatu perikatan. Kerugian adalah titik pertama dalam Segitiga Akuntansi Forensik. Landasannya adalah Pasal 1365 Kitab Undang-Undang Hukum Perdata yang berbunyi : "tiap perbuatan yang melanggar hukum dan membawa kerugian kepada orang lain, mewajibkan orang yang menimbulkan kerugian itu karena kesalahannya untuk menggantikan kerugian tersebut". Titik kedua dalam Segitiga Akuntansi Forensik adalah perbuatan melawan hukum. Tanpa perbuatan melawan hukum, tidak ada yang dapat dituntut untuk mengganti kerugian dan titik ketiga dalam Segitiga Akuntansi Forensik adalah adanya keterkaitan antara kerugian dan perbuatan melawan hukum atau ada hubungan kausalitas antara kerugian dan perbuatan melawan hukum. Perbuatan melawan hukum dan hubungan kausalitas adalah ranahnya para ahli dan praktisi hukum, sedangkan perhitungan besarnya kerugian adalah ranahnya para akuntan forensik. Pada Gambar 2.1 disajikan model Segitiga Akuntansi Forensik.

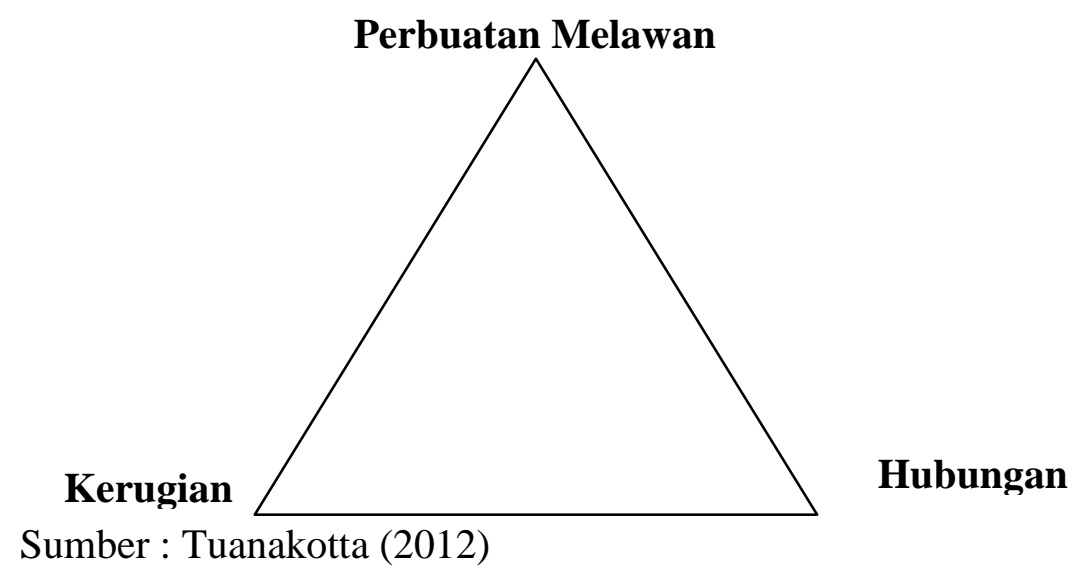

\section{Gambar 2.1 \\ Segitiga Akuntansi Forensik}

\subsubsection{Akuntansi Forensik terhadap Pencegahan (Preventif) Fraud}

Menurut Miqdad (2008), langkah-langkah untuk mencegah terjadinya fraud antara lain :

1. Membangun struktur pengendalian internal yang baik.

Dalam memperkuat pengendalian intern di perusahaan, COSO (The Committee of Sponsoring Organizations of The Treadway Commission) memperkenalkan suatu kerangka pengendalian yang lebih luas dari pada model pengendalian akuntansi yang tradisional dan mencakup manajemen risiko, yaitu pengendalian intern terdiri atas 5 (lima) komponen yang saling terkait yaitu:

a. Lingkungan Pengendalian (Control Environment)

b. Penilaian Resiko (Risk Assessment)

c. Kegiatan Pengendalian (Control Activities)

d. Informasi dan Komunikasi (Information and Communication)

e. Pemantauan (Monitoring) 
2. Mengefektifkan aktivitas pengendalian.

Mengefektifkan aktivitas pengendalian dengan cara review kinerja, pengolahan informasi, pengendalian fisik, dan pemisahan tugas.

3. Meningkatkan kultur organisasi.

Melalui implementasi prinsip-prinsip Good Corporate Governance meliputi:
a. Keadilan (Fairness)
b. Transparansi (Transparancy)
c. Akuntabilitas (Accountability)
d. Tanggung Jawab (Responsibility)
e. Moralitas (Morality)
f. Kehandalan (Reliability)
g. Komitmen (Commitment)

4. Mengefektifkan fungsi internal audit.

Beberapa hal yang harus diperhatikan oleh manajemen agar fungsi internal audit bisa efektif membantu manajemen dalam melaksanakan tanggung-jawabnya dengan memberikan analisa, penilaian, saran dan komentar mengenai kegiatan yang diperiksanya adalah :

a. Internal audit departemen harus mempunyai kedudukan yang independen dalam organisasi perusahaan.

b. Internal audit departemen harus mempunyai uraian tugas secara tertulis, sehingga setiap auditor mengetahui dengan jelas apa yang menjadi tugas, wewenang dan tanggungjawabnya.

c. Internal audit harus mempunyai internal audit manual.

d. Harus ada dukungan yang kuat dari top manajemen kepada internal audit departemen.

e. Internal audit departemen harus memiliki sumber daya yang profesional, capable, bisa bersikap objective dan mempunyai integritas serta loyalitas yang tinggi.

Menurut Pusat Pendidikan dan Pelatihan BPKP (2008), pencegahan fraud merupakan upaya terintegrasi yang dapat menekan terjadinya faktor penyebab fraud (fraud triangle), yaitu :

1. Memperkecil peluang terjadinya kesempatan untuk berbuat kecurangan,

2. Menurunkan tekanan kepada pegawai agar mampu memenuhi kebutuhannya,

3. Mengeliminasi alasan untuk membuat pembenaran/ rasionalisasi atas tindak kecurangan yang dilakukan.

\subsubsection{Akuntansi Forensik terhadap Pendeteksian (Detektif) Fraud}

Berikut adalah gambaran secara garis besar pendeteksian kecurangan berdasarkan penggolongan fraud oleh ACFE dalam Miqdad (2008) yaitu:

1 Kecurangan Laporan Keuangan (Financial Statement Fraud).

Kecurangan dalam penyajian laporan keuangan umumnya dapat dideteksi melalui analisis laporan keuangan sebagai berikut:

a. Analisis vertikal

b. Analisis horizontal

c. Analisis rasio

2 Penyalahgunaan aset (Asset Misappropriation)

Teknik untuk mendeteksi kecurangan-kecurangan kategori ini sangat banyak variasinya. Namun, pemahaman yang tepat atas pengendalian intern yang baik dalam pos-pos tersebut akan sangat membantu dalam melaksanakan pendeteksian kecurangan. Masing-masing jenis kecurangan dapat dideteksi melalui beberapa teknik yang berbeda.
a. Analytical review
b. Statistical sampling
c. Vendor or outsider complaints
d. Site visit-observation

3 Korupsi (Corruption) 
Sebagian besar kecurangan ini dapat dideteksi melalui keluhan dari rekan kerja yang jujur, laporan dari rekan, atau pemasok yang tidak puas menyampaikan komplain ke perusahaan. Pendeteksian atas kecurangan ini dapat dilihat dari karakteristik (red flags) penerima maupun pemberi.

Fraud dapat sedini mungkin terdeteksi jika manajemen atau internal auditor jeli melihat tanda-tanda fraud tersebut. Tunggal (2011) menyatakan tanda-tanda fraud tersebut beberapa diantaranya yaitu :

1. Terdapat perbedaan angka laporan keuangan yang mencolok dengan tahun sebelumnya.

2. Tidak ada pembagian tugas dan tanggung jawab yang jelas.

3. Seseorang menangani hampir semua transaksi yang penting.

4. Transaksi yang tidak didukung oleh bukti yang memadai.

5. Perkembangan perusahaan yang sulit.

\subsubsection{Audit Investigatif}

Jack Bologna dan Paul Shaw yang dikutip dalam Tunggal (2012) mengatakan audit fraud atau investigatif adalah keterampilan yang melampaui alam penggelapan dan penipuan manajemen perusahaan, atau penyuapan komersial. Memang, keterampilan akuntansi forensik melampaui wilayah umum kejahatan berkerah.

Menurut Pusdiklat BPKP (2008), audit investigatif merupakan sebuah kegiatan sistematis dan terukur untuk mengungkap kecurangan sejak diketahui, atau diindikasikannya sebuah peristiwa/kejadian/transaksi yang dapat memberikan kecukupan keyakinan, serta dapat digunakan sebagai bukti yang memenuhi pembuktian suatu kebenaran dalam menjelaskan kejadian yang telah diasumsikan sebelumnya dalam rangka mencapai keadilan. Pelaksanaan audit investigatif ditujukan untuk menentukan kebenaran permasalahan melalui proses pengujian, pengumpulan dan pengevaluasian bukti-bukti yang relevan dengan perbuatan fraud dan untuk mengungkapkan faktafakta fraud, mencakup:

1. Adanya perbuatan fraud (subyek)

2. Mengidentifikasi pelaku fraud (obyek)

3. Menjelaskan modus operandi fraud (modus)

4. Mengkuantifikasi nilai kerugian dan dampak yang ditimbulkannya.

\subsubsection{Audit Investigatif tehadap Penanganan Fraud (Represif)}

Audit investigatif dilakukan sebagai tindakan represif untuk menangani fraud yang terjadi. Strategi represif harus dilaksanakan terutama dengan diarahkan untuk memberikan sanksi hukum yang setimpal secara cepat dan tepat kepada pihak-pihak yang terlibat dalam praktik fraud. Dengan demikian, proses penanganan fraud sejak dari tahap penyelidikan, penyidikan dan penuntutan sampai dengan peradilan perlu dikaji untuk dapat disempurnakan di segala aspeknya sehingga proses penanganan tersebut akan dapat dilakukan secara cepat dan tepat (Tuanakotta, 2012).

Teknik-teknik dalam audit investigatif yang digunakan dalam penanganan fraud pada umumnya merupakan cara-cara umum dalam auditing, seperti pemeriksaan fisik, konfirmasi, memeriksa dokumen, review analitikal, meminta penjelasan lisan atau tertulis dari auditan, menghitung kembali, dan mengamati. Hanya dalam audit investigatif, teknik-teknik audit tersebut bersifat eksploratif, mencari "wilayah garapan" atau probing maupun pendalaman. Dalam audit investigatif teknik audit lebih ditekankan kepada review analitikal (Swarna, 2012).

\subsubsection{Hubungan antara Akuntansi Forensik, Audit Investigatif dan Fraud}

Pada Tabel 2.2 diperlihatkan keterkaitan antara akuntansi forensik dengan fraud audit (audit investigatif). 
Tabel 2.2 Akuntansi Forensik dan Audit Investigatif

\begin{tabular}{|c|c|c|c|c|c|}
\hline \multirow{3}{*}{$\begin{array}{c}\text { Jenis } \\
\text { Penugasan }\end{array}$} & \multicolumn{5}{|c|}{ Akuntansi Forensik } \\
\hline & \multicolumn{3}{|c|}{ Fraud Audit } & \multirow{4}{*}{$\begin{array}{c}\mathrm{A} \\
\mathrm{K} \\
\mathrm{U} \\
\mathrm{N} \\
\mathrm{T} \\
\mathrm{A} \\
\mathrm{N} \\
\mathrm{S} \\
\mathrm{I}\end{array}$} & \multirow{4}{*}{$\begin{array}{c}\mathrm{H} \\
\mathrm{U} \\
\mathrm{K} \\
\mathrm{U} \\
\mathrm{M}\end{array}$} \\
\hline & Proak & Aud & nvestigatif & & \\
\hline $\begin{array}{l}\text { Sumber } \\
\text { Informasi }\end{array}$ & $\begin{array}{c}\text { Risk } \\
\text { Assessment }\end{array}$ & $\begin{array}{c}\text { Temuan Audit, } \\
\text { Tuduhan, Keluhan, Tip }\end{array}$ & Temuan Audit & & \\
\hline Output & $\begin{array}{l}\text { Identifikasi } \\
\text { potensi fraud }\end{array}$ & $\begin{array}{l}\text { Indikasi awal adanya } \\
\text { fraud }\end{array}$ & $\begin{array}{l}\text { Bukti ada/tidaknya } \\
\text { pelanggaran }\end{array}$ & & \\
\hline
\end{tabular}

Sumber : Tuanakotta (2012)

Dari Tabel 2.2 diatas terlihat proses audit investigatif, akuntansi dan hukum. Audit investigatif dimulai pada bagian kedua audit fraud yang bersifat reaktif, yakni sesudah ditemukannya indikasi awal adanya fraud. Audit investigatif merupakan bagian dan titik awal dari akuntansi forensik. Tabel 2.2 diatas dapat dikembangkan lebih lanjut dengan memasukkan unsur tindak pidana, misalnya tindak pidana korupsi (tipikor). Dengan memasukkan unsur tipikor maka unsur akuntansinya adalah perhitungan kerugian keuangan negara dan proses (atau acara) pengadilan tipikor mulai dari tahap penyelidikan, penyidikan, penuntutan, pemeriksaan di sidang, putusan pengadilan dan upaya hukum (Tuanakotta, 2012).

\subsubsection{Pengelolaan Keuangan Daerah}

Permendagri Nomor 21 tahun 2011 tentang Perubahan Kedua atas Permendagri Nomor 13 tahun 2006 tentang Pedoman Pengelolaan Keuangan Daerah yang antara lain menjelaskan : Pengelolaan Keuangan Daerah adalah keseluruhan kegiatan yang meliputi perencanaan, pelaksanaan, penatausahaan, pelaporan, pertanggungjawaban dan pengawasan keuangan daerah.

Berdasarkan Undang-Undang No.33 tahun 2004 pasal 66 ayat 1, tentang azas umum pengelolaan keuangan daerah, menjelaskan bahwa keuangan daerah harus dikelola secara tertib, taat pada peraturan perundang-undangan, efisien ekonomis, efektif, transparan dan bertanggung jawab dengan memperhatikan asas keadilan, kepatuhan dan manfaat untuk masyarakat. Pengelolaan keuangan daerah dilaksanakan dalam suatu sistem yang terintegrasi yang diwujudkan dalam anggaran pendapatan dan belanja daerah (APBD).

\subsection{Penelitian Terdahulu}

Wiratmaja (2010) melakukan penelitian yang berjudul Akuntansi Forensik dalam Upaya Pemberantasan Tindak Pidana Korupsi. Hasil penelitian menunjukkan bahwa akuntansi forensik merupakan formulasi yang dapat dikembangkan sebagai strategi preventif, detektif, dan persuasif melalui penerapan prosedur akuntansi forensik dan audit investigatif yang bersifat litigation support untuk menghasilkan temuan dan bukti yang dapat digunakan dalam proses pengambilan putusan di pengadilan.

Okoye dan Gbegi (2013) melakukan penelitian dengan judul "Forensic Accounting : A Tool For Fraud Detection And Prevention In The Public Sector". Tujuan dari penelitian ini adalah untuk menguji akuntansi forensik sebagai alat untuk pencegahan dan pendeteksian fraud pada organisasi sektor publik di Negara bagian Kogi - Nigeria. Hasil penelitian Okoye dan Gbegi menunjukkan bahwa penerapan akuntansi forensik secara signifikan berpengaruh terhadap berkurangnya kasuskasus fraud yang terjadi di sektor publik. Penerapan Akuntansi forensik dapat membantu lebih baik dalam upaya pencegahan dan pendeteksian fraud di organisasi sektor publik.

Fauzan, Purnamasari, dan Gunawan (2015) melakukan penelitian berjudul Pengaruh Akuntansi Forensik dan Audit Investigasi terhadap Pengungkapan Fraud (Studi Kasus pada Badan Pengawasan Keuangan dan Pembangunan Perwakilan Jawa Barat). Tujuan dari penelitian ini adalah untuk mengetahui pengaruh akuntansi forensik serta audit investigasi yang dimiliki auditor terhadap pengungkapan fraud. Penelitian ini menggunakan metode penelitian deskriptif kuantitatif dengan 
menggunakan sampel auditor investigasi di BPKP Perwakilan Jawa Barat sebanyak 32 responden. Hasil penelitan menunjukkan bahwa akuntansi forensik serta audit investigasi berpengaruh sangat baik secara parsial maupun simultan terhadap pengungkapan fraud. Berdasarkan hasil analisis, hubungan yang kuat juga ditunjukkan kedua variabel bebas terhadap pengungkapan fraud 0.647(R), selain itu kemampuan yang ditunjukkan variabel-variabel independen dalam menjelaskan pengungkapan fraud sebesar 45,5\% $(\mathrm{R}$ square $=0.455)$ sedangkan 54,5\% dipengaruhi oleh variabel lain di luar penelitian ini.

Persamaan penelitian ini dengan beberapa penelitian yang telah dilakukan terletak pada variabel/ masalah penelitian yang sama yakni akuntansi forensik, audit investigatif, dan fraud (korupsi). Perbedaannya adalah penelitian terdahulu pada umumnya meneliti tentang pengaruh akuntansi forensik dan audit investigatif terhadap pengungkapan fraud di sektor publik dengan menggunakan desain penelitian kualitatif, sedangkan penelitian ini di desain dengan pendekatan kualitatif untuk menganalisis bagaimana aplikasi dan fungsi keefektifannya dari akuntansi forensik dan audit investigatif terhadap pencegahan, pendeteksian, dan penanganan fraud secara khusus dalam pengelolaan keuangan daerah.

\subsection{Pertanyaan Riset dan Proposisi}

\section{KERANGKA KONSEPTUAL}

Berdasarkan rumusan masalah yang telah ditetapkan pada bab sebelumnya dan berbasis pemikiran pada fenomena penanganan perkara fraudulance dan tindak pidana korupsi, pertanyaan spesifik yang dijadikan sebagai pertanyaan riset adalah sebagai berikut.

1. Apakah penerapan Akuntansi Forensik oleh Perwakilan BPKP Provinsi Sulawesi Utara telah teraplikasikan dan berfungsi secara efektif terhadap Pencegahan (Preventif) Fraud dalam Pengelolaan Keuangan Daerah?

2. Apakah penerapan Akuntansi Forensik oleh Perwakilan BPKP Provinsi Sulawesi Utara telah teraplikasikan dan berfungsi secara efektif terhadap Pendeteksian (Detektif) Fraud dalam Pengelolaan Keuangan Daerah?

3. Apakah penerapan Audit Investigatif oleh Perwakilan BPKP Provinsi Sulawesi Utara telah teraplikasikan dan berfungsi secara efektif terhadap Penindakan (Represif) Fraud dalam Pengelolaan Keuangan Daerah?

Setelah uraian dalam proses membangun pertanyaan riset diatas, pada langkah berikutnya adalah membangun proposisi yang tersusun sebagai berikut.

1. Proposisi pertama adalah Penerapan Akuntansi forensik berfungsi efektif dan aplikatif terhadap upaya Pencegahan (preventif) Fraud dalam Pengelolaan Keuangan Daerah;

2. Proposisi kedua adalah Penerapan Akuntansi Forensik berfungsi efektif dan aplikatif terhadap upaya Pendeteksian (detektif) Fraud dalam Pengelolaan Keuangan Daerah; dan

3. Proposisi ketiga adalah Penerapan Audit Investigatif berfungsi efektif dan aplikatif terhadap upaya Penanganan (represif) Fraud dalam Pengelolaan Keuangan Daerah.

\subsection{Model Analisis}

Berdasarkan rumusan masalah, pertanyaan riset dan proposisi yang telah dibangun sebelumnya, maka model/kerangka analisis penelitian ini dimulai dari menganalisis penerapan akuntansi forensik terhadap pencegahan (preventif) fraud dalam pengelolaan keuangan daerah dengan menganalisis aplikasi dari sistem-sistem pengendalian yang diterapkan oleh Perwakilan BPKP selaku APIP serta sejauhmana keefektifan dari fungsi sistem-sistem pengendalian tersebut untuk mencegah terjadinya fraud.

Setelah menganalisis aplikasi dan keefektifan fungsi dari sistem pencegahan fraud, kemudian dilakukan analisis terhadap metode-metode pendeteksian fraud yang merupakan penerapan akuntansi forensik baik secara aplikasi maupun keefektifan fungsinya. Bila suatu fraud dapat terdeteksi secara dini, maka sistem pendeteksian akan memberi feedback terhadap sistem pencegahan (menandakan bahwa sistem pengendalian berjalan dengan baik), sehingga fraud yang berpotensi untuk memberikan kerugian yang lebih besar dapat ditangkal lebih awal. Sedangkan 
apabila fraud sudah terlanjur terjadi yang merupakan pelanggaran terhadap hukum dan berakibat pada kerugian keuangan negara, maka proses selanjutnya harus ditangani secara represif melalui audit investigatif.

Selanjutnya dalam penanganan fraud yang terdeteksi, penerapan audit investigatif adalah langkah berikut untuk menangani dan memproses secara hukum fraud yang mengakibatkan kerugian keuangan negara. Pada tahap ini, dianalisis bagaimana penerapan audit investigatif secara aplikatif dalam penugasan audit investigatif, audit perhitungan kerugian keuangan negara, maupun pemberian keterangan ahli, serta bagaimana keefektifan fungsinya dalam menekan fraud dan potensi-potensi kerugian yang ditimbulkan (recovery kerugian), juga bisa berfungsi memberikan feedback terhadap sistem pencegahan dalam konteks pemberian efek jera terhadap para pelaku fraud. Pada Gambar 3.1 dipaparkan model analisis sebagai kerangka konseptual penelitian ini.

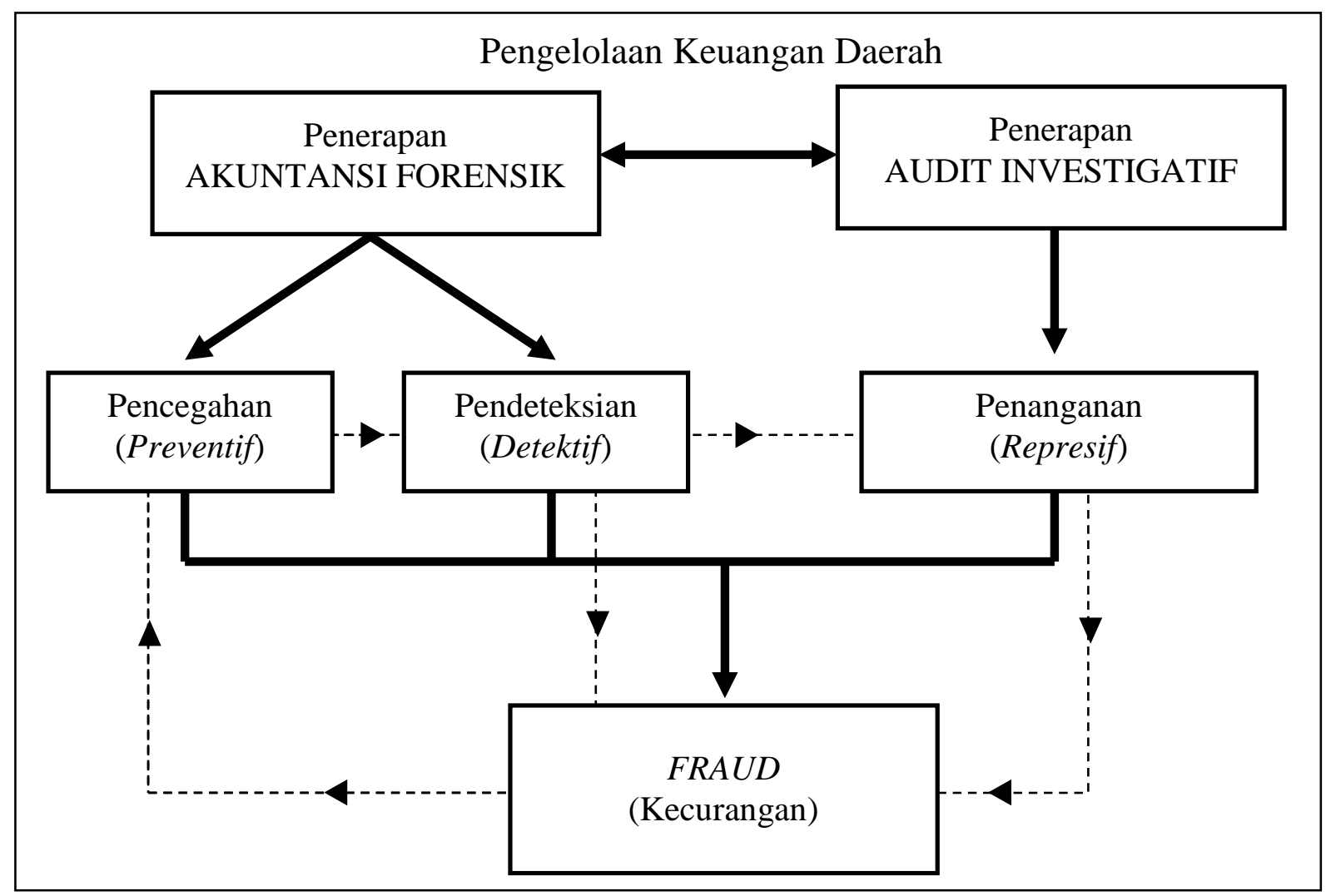

Sumber : data olahan.

\section{Gambar 3.1 Model Analisis}

\subsection{Jenis Penelitian}

\section{METODE PENELITIAN}

Studi ini ditinjau dari metode analisis dan desainnya adalah jenis penelitian kualitatif, dan bila ditinjau dari tingkat eksplanasinya merupakan jenis penelitian deskriptif. Metode kualitatif deskriptif dipandang sesuai, karena penelitian harus dilakukan secara teliti, mendalam dan menyeluruh untuk memperoleh gambaran mengenai prinsip-prinsip atau pola-pola yang berlaku umum sehubungan dengan gejala yang ada dalam objek penelitian. Jenis penelitian kualitatif desktriptif ini juga dipilih agar hasil yang dicapai dari penelitian ini dapat menjadi rekomendasi yang baik, jelas, dan berimbang bagi para pembuat keputusan dalam organisasi-organisasi terkait topik penelitian.

Penelitian kualitatif mengkaji perspektif partisipan dengan strategi-strategi yang bersifat interaktif dan fleksibel. Penelitian kualitatif ditujukan untuk memahami fenomena-fenomena sosial dari sudut pandang partisipan. Dengan demikian arti atau pengertian penelitian kualitatif tersebut adalah penelitian yang digunakan untuk meneliti pada kondisi objek alamiah dimana peneliti merupakan instrumen kunci (Sugiyono, 2005). Pada penelitian kualitatif ini, untuk penentuan 
sumber data (narasumber/ informan/partisipan) dilakukan secara purposive, yaitu dipilih dengan pertimbangan dan tujuan tertentu. Hasil penelitian metode kualitatif hanya berlaku untuk kasus situasi sosial tersebut, yang dapat ditransferkan atau diterapkan ke situasi sosial (tempat lain), apabila situasi sosial tersebut memiliki kemiripan atau kesamaan dengan situasi sosial yang diteliti (Sugiyono, 2014).

\subsection{Jenis dan Sumber Data}

Berdasarkan jenisnya, data digolongkan atas data numerik (kuantitatif), dan data kategorik (kualitatif).

1. Jenis data numerik (kuantitatif), merupakan data yang dinyatakan dalam besaran numerik/angka.

2. Jenis data kategorik (kualitatif), merupakan data yang diklasifikasikan berdasarkan kategori tertentu.

Berdasarkan sumbernya, sumber data terdiri dari sumber data primer dan sumber data sekunder.

1. Sumber data Primer, merupakan sumber data yang didapatkan atau dikumpulkan sendiri yakni diperoleh langsung peneliti dari informan/ partisipan melalui teknik observasi, dokumentasi, wawancara, pertanyaan tambahan, focus group discussion, dan sebagainya.

2. Sumber data Sekunder, merupakan sumber data yang diperoleh peneliti dari pihak lain (penyedia data) dalam hal ini Perwakilan BPKP Provinsi Sulawesi Utara, maupun dari sumber lain seperti situs internet, toko buku, dan lain-lain.

\subsection{Teknik Pengumpulan Data}

Teknik pengumpulan data yang dilakukan dalam penelitian ini adalah melalui studi pustaka (library research), observasi dan dokumentasi (observation and documentation), wawancara (interview) dan wawancara mendalam (in-depth interview), Focus Group Discussion (FGD), dan melalui pertanyaan tambahan (Additional Question).

\subsection{Teknik Pengujian Keabsahan Data}

Pengujian keabsahan data dalam penelitian kualitatif (data-data kualitatif) meliputi uji : credibility (validitas internal), transferability (validitas eksternal), dependability (reliabilitas), dan confirmability (obyektivitas). Menurut Sugiyono (2005), Triangulasi diartikan sebagai pengecekan data dari berbagai sumber dengan berbagai cara, dan berbagai waktu.

1. Triangulasi Sumber

Untuk menguji kredibilitas data dilakukan dengan cara mengecek data yang telah diperoleh melalui beberapa sumber.

2. Triangulasi Teknik

Triangulasi teknik untuk menguji kredibilitas data dilakukan dengan cara mengecek data kepada sumber yang sama dengan teknik yang berbeda.

3. Triangulasi Waktu

Data yang dikumpul dengan teknik wawancara di pagi hari pada saat narasumber masih segar, belum banyak masalah akan memberikan data yang lebih valid sehingga lebih kredibel.

Triangulasi dapat juga dilakukan dengan menggunakan teknik yang berbeda yaitu wawancara, observasi dan dokumen. Triangulasi ini selain digunakan untuk mengecek kebenaran data juga dilakukan untuk memperkaya data. Menurut Nasution (2013), selain itu triangulasi juga dapat berguna untuk menyelidiki validitas tafsiran peneliti terhadap data, karena itu triangulasi bersifat reflektif.

\subsection{Teknik Analisis}

Sugiyono (2014) menyatakan bahwa analisis data adalah proses mencari dan menyusun secara sistematis data yang diperoleh dari hasil wawancara, catatan lapangan, dan dokumentasi, dengan cara mengorganisasikan data ke dalam kategori, menjabarkan ke dalam unit-unit, 
melakukan sintesa, menyusun ke dalam pola, memilih mana yang penting dan yang akan dipelajari, dan membuat kesimpulan sehingga mudah dipahami oleh diri sendiri maupun orang lain.

Teknik analisis data dalam penelitian ini mengikuti konsep yang diberikan Miles dan Huberman dalam Sugiyono (2014), yaitu model analisis data yang dilakukan secara interaktif dan berlangsung terus menerus sampai tuntas, sehingga datanya sudah jenuh. Aktivitas dalam analisis data, yaitu data reduction, data display, dan conclusion drawing/verification.

\section{HASIL ANALISIS DAN PEMBAHASAN}

\subsection{Hasil Penelitian}

\subsubsection{Potensi dan Tren Fraud dalam Pengelolaan Keuangan Daerah di Sulawesi Utara}

Tabel 5.1 Rekapitulasi Temuan Setelah Tindak Lanjut Perwakilan BPKP Provinsi Sulawesi Utara Tahun 2011-2015

\begin{tabular}{|c|c|c|}
\hline \multirow{2}{*}{$\begin{array}{c}\text { Tahun } \\
\text { Pengawasan }\end{array}$} & $\begin{array}{c}\text { Jumlah Kasus } \\
\text { (Kejadian) }\end{array}$ & $\begin{array}{c}\text { Nilai Kerugian Negara } \\
\text { (Rp.) }\end{array}$ \\
\hline 2011 & 217 & 2.242 .898 .390 \\
\hline 2012 & 158 & 716.081 .826 \\
\hline 2013 & 80 & 2.803 .629 .255 \\
\hline 2014 & 123 & 6.273 .867 .322 \\
\hline 2015 & 181 & 2.595 .301 .306 \\
\hline
\end{tabular}

Sumber : Perwakilan BPKP Provinsi Sulawesi Utara, LHP 2012-2015 - data olahan.

Tabel 5.2 Hasil Audit Investigatif dan Audit Penghitungan Kerugian Keuangan Negara di Wilayah Provinsi Sulawesi Utara Tahun 2012 - 2015

\begin{tabular}{|c|l|c|c|c|c|c|c|c|c|}
\hline \multirow{2}{*}{ No. } & \multirow{2}{*}{ Instansi } & \multicolumn{9}{c|}{ Jumlah Kasus (Laporan) } \\
\cline { 3 - 10 } & & \multicolumn{2}{|c|}{2012} & \multicolumn{2}{c|}{$\mathbf{2 0 1 3}$} & \multicolumn{2}{|c|}{2014} & \multicolumn{2}{c|}{$\mathbf{2 0 1 5}$} \\
\cline { 3 - 10 } & & AI & PKKN & AI & PKKN & AI & PKKN & AI & PKKN \\
\hline 1 & Satuan Kerja K/L & - & - & - & - & - & - & - & - \\
\hline 2 & Pemprov & - & 1 & 2 & - & - & 1 & - & - \\
\hline 3 & Pemkab & 1 & 7 & 2 & 8 & 3 & 11 & 2 & 9 \\
\hline 4 & Pemkot & - & 3 & 1 & 6 & - & 2 & 1 & 2 \\
\hline 5 & BUMN & - & - & - & - & - & - & - & - \\
\hline 6 & BUMD & 1 & 1 & - & - & - & - & - & - \\
\hline \multicolumn{2}{r}{ Jumlah } & $\mathbf{1}$ & $\mathbf{1 2}$ & $\mathbf{5}$ & $\mathbf{1 4}$ & $\mathbf{3}$ & $\mathbf{1 7}$ & $\mathbf{3}$ & $\mathbf{1 1}$ \\
\hline
\end{tabular}

Sumber : Perwakilan BPKP Provinsi Sulawesi Utara, LHP 2012-2015 - data olahan.

\subsubsection{Sistem Pencegahan Fraud sebagai Aplikasi Penerapan Akuntansi Forensik}

1. Sistem Pengendalian Intern Pemerintah (SPIP)

Penyelenggaraan dan implementasi SPIP pada Pemerintah Daerah sebagai bentuk upaya pencegahan fraud berupa kegiatan-kegiatan berikut ini.

1) Penyusunan Pedoman Pembinaan/ Penyelenggaraan SPIP, sampai akhir tahun 2014 Satuan Tugas Pembinaan dan Penyelenggaraan (Satgas PP) SPIP telah mengeluarkan 15 buah Pedoman Umum yang ditetapkan oleh Peraturan Kepala BPKP terkait pelaksanaan/ penyelenggaraan SPIP dan sebanyak 26 buah Pedoman Teknis;

2) Sosialisasi SPIP, telah dilakukan oleh Satgas PP SPIP sebanyak 392 Pemerintah Daerah sampai akhir tahun 2014;

3) Bimbingan dan Konsultasi melalui 3 kegiatan, yaitu : 
a. Pemetaan / Diagnostic Assesment, mulai dari tahun 2010 sampai dengan tahun 2012 telah dilaksanakan kepada 238 Pemerintah Daerah dari 524 Pemerintah Daerah yang ada atau sebesar $45,23 \%$.

b. Peraturan Penyelenggaraan SPIP, sampai dengan akhir tahun 2012 telah dilakukan bimbingan teknis dalam bentuk penerbitan Peraturan Kepala Daerah (Perkada) terkait Penyelenggaraan SPIP bagi Instansi Pemerintah sebanyak 524 Perkada terdiri dari 33 Perkada Provinsi, 398 Perkada Kabupaten, dan 93 Perkada Kota.

c. Penyusunan Dokumen Desain Penyelenggaraan SPIP.

4) Peningkatan Kompetensi Auditor APIP.

Pendidikan dan Pelatihan (Diklat) SPIP, telah digalakan oleh Satgas PP SPIP sejak tahun 2010-2014 berupa diklat dan workshop SPIP yang dilaksanakan melalui Pusdiklat BPKP maupun masing-masing Perwakilan di daerah.

\section{Fraud Control Plan (FCP)}

BPKP secara khusus sedang dan terus mengembangkan pengendalian yang dirancang secara spesifik untuk mencegah, menangkal, dan memudahkan pengungkapan kejadian yang berindikasi korupsi. Sistem tersebut ditandai dengan adanya atribut-atribut yang spesifik yang merupakan pendalaman atau penguatan dari sistem tata kelola setiap organisasi yang telah ada yang dipengaruhi oleh situasi dan kondisi masing-masing organisasi. Sistem pengendalian tersebut kemudian diistilahkan dengan sebutan Fraud Control Plan (FCP).

Dalam penerapannya, FCP terdiri dari 10 atribut spesifik yang harus dibangun di setiap organisasi pemerintah yang nantinya akan menjadi parameter untuk dievaluasi. Atribut atribut tersebut terdiri dari : Kebijakan Terintegrasi, Struktur Pertanggungjawaban, Penilaian Risiko Fraud, Kepedulian Karyawan, Kepedulian Pelanggan Masyarakat, Perlindungan Pelapor, Sistem Pelaporan Fraud, Pelaporan Eksternal, Standar Investigasi, dan Standar Perilaku dan Disiplin.

Tahapan (siklus) dalam pelaksanaan FCP terdiri dari tahap sosialisasi, komitmen instansi, evaluasi Program Anti Korupsi (PAK), pemaparan hasil evaluasi, pelaporan, serta tindak lanjut dan monitoring yang nantinya menjadi feedback dalam evaluasi PAK. Pelaksanaan FCP lebih dititikberatkan pada hasil evaluasi sebagai pendekatan utamanya yang tersusun dari alat utama program evaluasi, alat pendukung penggalian persepsi dan alat pendukung Fraud Risk Assessment.

\section{Sistem Informasi Manajemen Daerah (SIMDA)}

Sampai dengan bulan Januari 2016, Program Aplikasi SIMDA telah diimplementasikan pada 425 Pemda dari 542 pemerintah daerah yang ada atau sebanyak $78,41 \%$, dengan rincian disajikan pada Tabel 5.3.

Tabel 5.3 Pengguna SIMDA di Pemerintah Daerah

\begin{tabular}{|c|l|c|}
\hline No. & \multicolumn{1}{|c|}{ Jenis Implementasi } & Januari 2016 \\
\hline 1 & Pengguna SIMDA & 425 Pemda \\
\hline 2 & SIMDA Keuangan & 365 Pemda \\
\hline 3 & SIMDA BMD & 347 Pemda \\
\hline 4 & SIMDA Gaji & 69 Pemda \\
\hline 5 & SIMDA Pendapatan & 55 Pemda \\
\hline
\end{tabular}

Sumber : BPKP, 2016.

Keunggulan dan manfaat dari penggunaan SIMDA antara lain adalah :

1. SIMDA di desain berdasarkan sistem informasi pengelolaan keuangan daerah sesuai dengan peraturan perundang-undangan yang berlaku; 
2. Aplikasi SIMDA dapat diimplementasikan untuk pengelolaan keuangan daerah secara terintegrasi, menggunakan teknologi multi user dan teknologi client/server dari penyusunan anggaran, pelaksanaan anggaran, dan pertanggungjawaban keuangan, sehingga mempunyai keuntungan pengendalian transaksi yang terjamin, efisien dalam melakukan penatausahaan, cepat dan akurat dalam menghasilkan informasi keuangan;

3. Dapat memberikan transfer knowledge dalam rangka meningkatkan kompetensi dan kapasitas SDM pemerintah daerah berupa penguasaan disiplin ilmu akuntansi dan audit, penguasaan business process pengelolaan keuangan daerah, dan pengalaman praktis pengelolaan keuangan daerah;

4. Pemeliharaan yang berkesinambungan dalam rangka pengembangan dan perbaikan Aplikasi SIMDA; dan

5. Mudah digunakan karena memiliki fitur-fitur yang sederhana, mudah dimengerti dan dipelajari.

\subsubsection{Metode Pendeteksian Fraud sebagai Aplikasi Penerapan Akuntansi Forensik \\ 1. Audit Operasional (Operational Audit)}

Audit operasional adalah pemeriksaan yang sistematis terhadap kegiatan, program organisasi dan seluruh atau sebagian dari aktivitas dengan tujuan menilai dan melaporkan apakah sumber daya dan dana digunakan secara ekonomis dan efisien dan apakah tujuan program, kegiatan, aktivitas, yang telah direncanakan dapat dicapai (efektif) dengan tidak bertetangan dengan peraturan, ketentuan dan undang-undang yang berlaku. Audit operasional merupakan evaluasi mengenai kegiatan operasional organisasi yang dirancang guna menilai tingkat efektivitas, efisiensi, dan keekonomisan dalam pelaksanaan kegiatan/ program.

Prosedur pelaksanaan audit operasional meliputi beberapa tahap, sebagai berikut:

1) Persiapan Audit

Persiapan audit bertujuan untuk mengumpulkan informasi, penelaahan peraturan, ketentuan dan undang-undang yang berkaitan dengan aktifitas yang di audit serta menganalisis informasi yang diperoleh guna mengidentifikasi hal-hal yang potensial mengandung titik kelemahan.

Cara memperoleh informasi dalam tahap Persiapan audit ini dapat dilakukan dengan beberapa pendekatan yang dapat juga mendeteksi adanya fraud:

a. pembicaraan dengan Pimpinan obyek pemeriksaan

b. wawacara dengan pihak lainnya

c. pemeriksaan fisik

d. mereview laporan hasil audit sebelumnya

e. pengujian transaksi

f. mereview laporan manajemen

g. data flow diagram dan sistem flow card

h. bagan arus

2) Pengujian Pengendalian Manajemen

Pengujian pengendalian manajemen dilakukan untuk menentukan tingkat resiko penyalahgunaan sumberdaya dan melakukan penilaian terhadap penilaian pengendalian manajemen. Untuk menentukan tingkat resiko, sebelumnya tim auditor harus memperhatikan beberapa hal antara lain :

a. memperhatikan setiap lampu merah yang dilihat dalam informasi mengenai instansi pemerintah yang diaudit.

b. memperhatikan dukungan dari manajemen apakah manajemen meyakini pentingnya pengendalian-pengendalian manajemen dan sudah membuat suatu komitmen untuk mengimplementasikannya.

c. memperhatikan tingkat kecukupan para pimpinan dan karyawan dari instansi yang diaudit. 
Setelah mempertimbangkan unsur-unsur diatas kemudian tim menilai apakah tingkat resiko keseluruhan tinggi, sedang ataukah rendah. Setelah menilai tingkat resiko, tim audit menilai efektivitas sistem pengendalain obyek audit kemudian memeriksa pengendalian manajemen apakah pengendalian manajemen tersebut logis, cukup lengkap dan mungkin mendeteksi fraud yang mungkin terjadi.

3) Pemeriksaan Lanjutan

Pemeriksaan lanjutan ini bertujuan untuk mendapatkan bukti-bukti yang cukup, guna mendukung sasaran definitif pemeriksaan yang telah diperoleh pada tahap pengujian dan pengajian ulang sistem pengendalian manajemen.

4) Pelaporan Hasil Audit

Atas dasar Kertas Kerja Pemeriksaan, ketua bersama dengan tim menyusun Laporan Hasil Audit. Laporan Hasil Audit terdiri atas Kertas Kerja Pemeriksaan dan rekomendasi perbaikan atas kelemahan pengendalian dari Instansi Pemerintah yang diaudit.

\section{Probity Audit (Audit Pengadaan Barang/Jasa)}

Banyak kasus korupsi yang melibatkan minimal kepala daerah merupakan kasus yang berkaitan dengan pengadaan barang/ jasa dan kasus penyimpangan (fraud) tersebut terjadi pada tahap perencanaan. Oleh karena itu dipandang perlu dilakukan prosedur audit mulai pada saat identifikasi kebutuhan dalam penyusunan Rencana Umum Pengadaan (RUP) yang merupakan bagian dari penyusunan RKA SKPD. Data-data menyebutkan bahwa :

- 85\% kasus korupsi yang melibatkan minimal 306 Gubernur/ Bupati/ Walikota adalah kasus Pengadaan Barang/Jasa (PBJ).

- Penelitian KPK menyebutkan ada $>70 \%$ kasus korupsi berasal dari PBJ.

- 3.423 kasus korupsi yang ditangani BPKP sejak tahun 2003 adalah kasus PBJ.

Hal mendasari diterbitkannya pedoman probity audit yaitu untuk mendorong peran dan fungsi APIP dalam prevent, deter dan detect sebagai Early Warning System atas proses pengadaan barang dan jasa serta dalam rangka peningkatan kualitas akuntabilitas keuangan negara melalui pengelolaan keuangan negara yang efektif, efisien, transparan, dan akuntabel.

Dampak yang dihasilkan dari proses pengadaan barang/jasa yang memenuhi prinsipprinsip probity yaitu:

1) menghindari konflik dan permasalahan.

2) menghindari praktek korupsi.

3) meningkatkan integritas sektor publik melalui perubahan perilaku dan perubahan organisasi.

4) memberi keyakinan kepada masyarakat bahwa penyelenggaraan kegiatan sektor publik telah dilakukan melalui proses yang berintegritas dan dapat dipercaya.

5) memberikan keyakinan secara objektif dan independen atas kejujuran (probity) proses pengadaan barang/jasa.

6) meminimalkan potensi adanya litigasi (permasalahan hukum).

Perwakilan BPKP Provinsi Sulawesi Utara telah melakukan kegiatan pengawasan berupa assurance dan consulting dengan tujuan memberikan masukan agar proses Pengadaan Barang/Jasa dilakukan secara efisien sesuai dengan ketentuan yang berlaku dan aset yang dicatat mencerminkan kondisi yang sebenarnya.

\section{EDP Audit : Computer Forensic}

BPKP perlu dan harus dapat memiliki auditor dengan kemampuan untuk mengevaluasi keterandalan (reliability) sistem teknologi informasi yang diterapkan oleh institusi atau badan usaha untuk menghasilkan laporan kinerja atau laporan keuangan instansi/ badan usaha tersebut. Maka dibentuklah Gugus Tugas (Taskforce) EDP Auditor, yang pada saat ini bernaung di Deputi Bidang Akuntan Negara BPKP Pusat. 
Electronic Data Processing (EDP) Audit adalah jasa audit yang disediakan oleh BPKP yang mencakup jasa audit atau review atas risiko-risiko yang terkait langsung dengan Teknologi Informasi (TI) yang mengancam Institusi Pemerintah Pusat/ Daerah (Departemen/Kementerian atau Dinas) dan Badan-Badan Usaha Milik Negara/ Daerah.

Salah satu jasa EDP Audit yang bersifat assurance adalah Computer Information Mining yang merupakan penerapan Computer Forensic (komputer forensik). Jasa ini dimaksudkan untuk membantu memberikan akses yang cepat kepada manajemen dan stakeholder lainnya tentang informasi komputer yang penting yang mungkin tidak tersedia dalam sistem pelaporan yang ada saat ini. Kegiatan ini seringkali dilaksanakan untuk menganalisis, mengarahkan dan menyelesaikan suatu kejadian bisnis yang tidak biasa dan tidak diperkirakan, seperti kecurangan atau fraud.

Penerapan computer forensic dapat langsung dipraktekkan dalam penugasan audit sehari-hari, misalnya dalam audit pengadaan barang dan jasa yang sudah menggunakan $e$ Tendering. Seorang auditor dituntut untuk bisa menyesuaikan diri dengan auditan tentang pengetahuannya dalam komputer forensik. Manfaat yang sangat besar dari komputer forensik dalam pendeteksian maupun pengungkapan suatu fraud (penyimpangan dan pelanggaran yang bisa berakibat pada kerugian negara) dipandang perlu untuk digunakan sebagai alat bantu dalam melakukan pemeriksaan, secara khusus dalam audit investigatif.

Untuk dapat mendeteksi terjadinya fraud dengan menggunakan keahlian computer forensik, auditor harus peka terhadap petunjuk atau jejak yang berindikasikan terjadinya fraud yang dapat menjadi obyek forensik, diantaranya :

1) Log file atau catatan aktivitas penggunaan komputer yang tersimpan secara rapi dan detail di dalam sistem;

2) File yang sekilas telah terhapus secara sistem, namun secara teknikal masih bisa diambil dengan cara-cara tertentu;

3) Catatan digital yang dimiliki oleh piranti pengawas trafik seperti IPS (Intrusion Prevention System) dan IDS (Intrusion Detection System);

4) Hard disk yang berisi data/ informasi backup dari sistem utama;

5) Rekaman e-mail, mailing list, blog, chat, dan mode interaksi dan komunikasi lainnya;

6) Beraneka ragam jenis berkas file yang dibuat oleh sistem maupun aplikasi untuk membantu melakukan manajemen file;

7) Rekam jejak interaksi dan trafik via internet dari satu tempat ke tempat yang lain (dengan berbasis IP address misalnya);

8) Absensi akses server atau komputer yang dikelola oleh sistem untuk merekam setiap adanya pengguna yang login ke piranti terkait; dan lain sebagainya.

\section{Layanan Pengaduan (Whistleblower System)}

Whistleblower System (WBS) adalah sistem pelaporan pelanggaran yang memungkinkan peran aktif pegawai dan pihak eksternal organisasi (masyarakat umum) untuk menyampaikan pengaduan mengenai tindakan pelanggaran dan dugaan pelanggaran yang dilakukan baik internal BPKP maupun eksternal organisasi dalam penyelenggaraan pemerintahan khususnya terhadap pengelolaan keuangan negara.

Whistleblower System BPKP dapat menjadi pintu masuk untuk dilakukannya suatu pemeriksaan khusus (investigasi) atas dugaan terjadinya suatu fraud dalam pengelolaan keuangan di sektor publik. BPKP Menyediakan ruang bagi pelapor untuk melaporkan dan/atau mengungkapkan fakta terjadinya pelanggaran dan indikasi fraud yang dapat menyebabkan kerugian keuangan negara, termasuk pelanggaran atas peraturan dan ketentuan dalam rangka penegakan hukum dan perbaikan sistem manajemen pemerintah. 


\subsubsection{Penugasan Audit Investigatif dalam Penanganan Fraud \\ 1. Audit Investigatif}

Pengawasan represif dapat dilakukan melalui audit investigatif sebagai tindak lanjut dari kelemahan yang ditemukan dalam rancangan dan penerapan fraud control plan maupun pengaduan yang diterima, yang mencakup reviu dokumen keuangan untuk tujuan khusus, yang dapat dipergunakan untuk litigasi di sidang peradilan dan penyelesaian kerugian keuangan negara, sama seperti kasus-kasus tindak pidana korupsi.

Audit investigatif sangat berperan dalam pengungkapan tindak pidana korupsi (fraud), yang dilakukan dengan :

1) mengungkap kasus dan modus operandi,

2) menetapkan sebab-sebab penyimpangan dan rekomendasi,

3) mengindentifikasi pihak-pihak yang diduga terkait/bertanggungjawab,

4) menghitung jumlah kerugian keuangan negara.

Secara internal, BPKP melakukan penugasan audit investigatif berdasarkan peraturan Kepala BPKP Nomor : PER-1314/K/D6/2012 tentang Pedoman Penugasan Bidang Investigasi. Permintaan penugasan bidang investigasi berasal dari:

1) Pengembangan Hasil Audit Operasional

2) Pengaduan Masyarakat

3) Permintaan Instansi Penyidik/Penetapan Pengadilan

4) Permintaan Objek Penugasan

Dalam pemeriksaan yang dilakukan Perwakilan BPKP Provinsi Sulawesi Utara dalam hal ini bidang Investigasi berdasarkan permintaan Aparat Penegak Hukum (APH) atas 16 Pemerintah Daerah di Wilayah Provinsi Sulawesi Utara pada tahun 2015, telah dilakukan audit investigatif sebanyak 3 laporan/ kasus dengan total indikasi kerugian keuangan negara sebesar Rp 5.567.375.159,40.

\section{Audit Dalam Rangka Penghitungan Kerugian Keuangan Negara}

Audit dalam rangka Penghitungan Kerugian Keuangan Negara (PKKN) adalah audit dengan tujuan tertentu yang dimaksudkan untuk menyatakan pendapat mengenai nilai kerugian keuangan negara yang timbul dari suatu kasus penyimpangan (fraud) dan digunakan untuk mendukung tindakan litigasi.

Pada tahun 2015, Perwakilan BPKP Provinsi Sulawesi Utara telah melakukan audit PKKN untuk menyatakan pendapat mengenai nilai kerugian negara yang timbul dari kasus penyimpangan guna mendukung tindakan ligitasi atas permintaan APH sebanyak sebanyak 11 laporan dengan total nilai kerugian negara sebesar Rp.8.726.914.493,24.

\section{Pemberian Keterangan Ahli}

Pemberian keterangan ahli adalah pemberian pendapat berdasarkan keahlian profesi auditor BPKP (di bidang akuntansi dan auditing) dalam suatu kasus tindak pidana korupsi dan/atau perdata untuk membuat terang suatu kasus bagi penyidik dan/atau hakim. Penugasan pemberian keterangan ahli meliputi pelaksanaan pemberian keterangan ahli kepada penyidik, jaksa penuntut umum, dan di hadapan hakim dalam sidang pengadilan yang dilaksanakan berdasarkan permintaan penyidik, permintaan jaksa penuntut umum, atau penetapan hakim, serta merupakan kelanjutan dari audit investigatif.

Pada tahun 2015, Perwakilan BPKP Provinsi Sulawesi Utara telah melakukan Pemberian Keterangan Ahli kepada penyidik Kejaksaan sebanyak 8 kasus dan penyidik Kepolisian sebanyak 9 kasus. Selain kepada penyidik, Perwakilan BPKP Provinsi Sulawesi Utara juga telah melakukan Pemberian Keterangan Ahli di Pengadilan Tindak Pidana Korupsi pada tahun 2015 sebanyak 13 kasus. 


\subsection{Analisis dan Pembahasan}

5.2.1 Analisis Penerapan Akuntansi Forensik untuk Pencegahan (Preventif) Fraud dalam Pengelolaan Keuangan Daerah

Beberapa hasil wawancara serta data dan informasi yang diperoleh, ada beberapa alasan penting mengapa strategi pencegahan fraud harus lebih diprioritaskan dibandingkan dengan langkah pendeteksian dan penindakan fraud, yaitu sebagai berikut :

- Apabila telah terjadi, fraud mengakibatkan kerugian keuangan yang cukup besar;

- Hasil recovery atas uang negara yang dikorupsi (fraud) sangat kecil;

- Kasus korupsi ( fraud), merusak reputasi baik institusi maupun individu;

- Proses litigasi menyita waktu dan biaya yang cukup banyak baik bagi aparat penegak hukum maupun calon tersangka;

- Semakin lama kejadian korupsi (fraud) tidak terungkap, semakin memberi peluang pelaku korupsi (fraud) untuk menutupi tindakannya dengan kecurangan yang lain.

Berdasarkan hasil penelitian yang telah diuraikan sebelumnya, menyebutkan bahwa upaya BPKP dalam melakukan pencegahan (preventif) terjadinya fraud dalam pengelolaan keuangan daerah adalah melalui penerapan :

1. Sistem Pengendalian Intern Pemerintah (SPIP)

2. Fraud Control Plan (FCP), dan

3. Sistem Informasi Manajemen Daerah (SIMDA)

Dari hasil penelitian tersebut dapat dianalisa bahwa penerapan akuntansi forensik dalam pengelolaan keuangan daerah adalah sangat relevan khususnya dalam upaya pencegahan fraud melalui tools-tools atau sistem aplikatif yang sudah dibangun yaitu : Fraud Control Plan (FCP) yang merupakan pengendalian khusus untuk pencegahan fraud, SPIP sebagai pengendalian secara umum dalam setiap tahapan pengelolaan keuangan daerah mulai dari perencanaan penganggaran, pelaksanaan, pelaporan dan pertanggungjawaban sampai monitoring dan evaluasi, serta SIMDA yang secara khusus sebagai sistem informasi yang akan menghasilkan output dari hasil pengelolaan keuangan daerah yang sudah dikendalikan. Dengan kata lain, setiap tools yang sudah ada baik FCP, SPIP dan SIMDA adalah sistem yang aplikatif diterapkan terhadap pencegahan fraud dalam pengelolaan keuangan daerah.

Melihat kegunaan dan manfaatnya, FCP, SPIP dan SIMDA adalah tools yang berfungsi efektif dalam menangkal dan mencegah terjadinya fraud dalam pengelolaan keuangan daerah, karena pada dasarnya setiap sistem yang dibangun ini bukan saja merupakan hard control (sistem, metode dan infrastruktur) yang handal untuk meminimalisir adanya kesempatan (opportunity) bagi para pelaku fraud melakukan aksinya, tetapi sebenarnya didalamnya juga mengandung unsur-unsur soft control seperti komitmen dan integritas pada sub unsur lingkungan pengendalian dalam SPIP, demikian juga yang ada pada atribut-atribut FCP. Sehingga faktor tekanan (pressure) dan pembenaran (razionalitation) dari para pelaku fraud seharusnya dapat berkurang dari waktu ke waktu karena sistem-sistem ini berfungsi efektif untuk melakukan pencegahan (preventif) fraud.

Hasil analisis lebih lanjut ditemukan bahwa penerapan SIMDA walaupun sudah optimal diterapkan tetapi tidaklah cukup, karena didapati fraud justru terjadi sebelum datadata dan informasi transaksi keuangan dimasukan dalam SIMDA, dengan kata lain pointnya ada pada pembuatan bukti-bukti transaksi yang seringkali dibuat fiktif atau bentuk kecurangan lainnya sebelum dipertanggungjawabkan dan diinput dalam SIMDA. Jadi dalam upaya pencegahan fraud, lebih diharapkan pada optimalnya FCP dan SPIP.

Untuk penerapan SPIP telah dilaksanakan dengan cukup optimal berdasarkan hasil evaluasi penerapan SPIP yang sudah dilakukan oleh BPKP, melalui pembuatan instrumen dalam bentuk pedoman-pedoman teknis, melakukan sosialisasi, bimbingan dan konsultasi (diagnostic assessment), diklat/workshop, pembentukan peraturan Kepala Daerah dan Satgas-satgas SPIP di daerah, namun upaya-upaya itu belum dilakukan secara merata ditiap daerah, konsisten, serta dibarengi dengan strategi untuk mendorong peran APIP di daerah 
(Inspektorat Provinsi/Kabupaten/Kota) sebagai mitra kerja BPKP dalam melakukan fungsi yang sama sebagaimana yang ada di BPKP, hal tersebut dapat dilihat dari kondisi kualitas dan kapasitas APIP yang ada di Pemerintah Daerah Sulawesi Utara yaitu rata-rata berada di level 1 (initial) sampai tahun 2015 (hanya ada 3 Pemda : Provinsi Sulut, Kota Manado dan Kota Kotamobagu yang sudah naik ke level 2) sementara level APIP di Perwakilan BPKP Sulut sudah ada pada level 3 yang selain memberikan assurance juga dapat berfungsi sebagai consultant.

Faktor-faktor penyebab belum optimalnya sistem-sistem pengendalian yang ada secara khusus FCP, sehingga belum bisa berfungsi efektif pada tataran realitanya, baru efektif pada tataran konsepnya. Hal lain yang bisa menjadi ukuran utama atas belum optimalnya pelaksanaan FCP ini belum ada satu pun pemerintah daerah di Sulawesi Utara, yang telah menyusun atribut/ komponen dari FCP. Faktor lainnya yang dapat diperhatikan adalah bagaimana peran APIP di daerah yang kurazng aktif dalam melakukan pencegahan terhadap fraud, komitmen dan respon yang kurang, mulai dari pimpinan daerah, pimpinan SKPD, sampai level aparatur pelaksana.

\subsubsection{Analisis Penerapan Akuntansi Forensik untuk Pendeteksian (Detektif) Fraud dalam Pengelolaan Keuangan Daerah}

Pada hasil penelitian diatas berdasarkan data-data dan pengamatan yang dilakukan, telah diuraikan pendeteksian fraud dalam pengelolaan keuangan daerah sebagai bentuk penerapan dari akuntansi forensik, diaplikasikan melalui :

1. Audit Operasional (Operational Audit),

2. Audit Pengadaan Barang/Jasa (Probity Audit),

3. Audit Electronic Data Processing (EDP) : Computer Forensic, dan

4. Whistleblower System (layanan pengaduan).

Penerapan akuntansi forensik terhadap pendeteksian fraud dalam pengelolaan keuangan daerah melalui Audit operasional, probity audit, Computer forensic (EDP Audit), dan Whistleblower system (WBS) adalah metode yang aplikatif, seringkali menjadi tools yang diandalkan BPKP dalam mendeteksi maupun mengungkap fraud.

Melalui audit operasional seringkali BPKP mendeteksi adanya kecurangan atau penyimpangan yang menjadi temuan dalam pemeriksaan (reviu) yang dilakukan sehingga Audit Operasional berfungsi efektif dalam mendeteksi adanya suatu fraud bahkan pengembangannya bisa dilanjutkan dengan audit investigatif untuk mengungkap kasus korupsi, dan perbuatan melanggar hukum lainnya yang berakibat pada kerugian keuangan negara. Demikian juga dengan Probity Audit yang secara khusus berfungsi efektif untuk mendeteksi fraud dalam proses pengadaan barang/jasa yang menjadi sektor yang rentan dengan korupsi. Kemudian juga EDP Audit (Computer Forensic) dan Whistleblower System sebagai bentuk terobosan baru dengan memanfaatkan kecanggihan teknologi informasi yang berfungsi efektif untuk melakukan pendeteksian fraud melalui teknik-teknik dengan bantuan komputer dan alat-alat digital begitu juga dengan sistem pengaduan dalam bentuk layanan pengaduan online.

Namun dalam evaluasi penerapannya, baik Computer Forensic maupun Whistleblower System masih ada pada tahap pengembangan karena masih tergolong baru. Di Perwakilan BPKP Provinsi Sulawesi Utara sendiri, sedang dalam upaya membekali para auditornya dalam menguasai ilmu dan teknik-teknik dalam computer forensic melalui training/diklat computer forensic, sedangkan untuk Whistleblower System, BPKP baru memanfaatkannya secara internal, untuk pelapor dari pihak eksternal, BPKP baru sebatas mengintegrasikannya dengan sistem pengaduan LAPOR! (Layanan Aspirasi dan Pengaduan Online Rakyat) yang diinisiasi dan dikembangkan oleh Kantor Staf Kepresidenan.

Dalam hal ini Computer Forensic maupun Whistleblower System masih belum optimal diterapkan. Sementara untuk Audit Operasional dinilai sudah optimal dalam penerapannya karena menjadi tugas dan fungsi yang reguler dijalankan oleh APIP baik Perwakilan BPKP 
maupun Inspektorat Provinsi/ Kabupaten/ Kota dalam melakukan reviu selama ini, dan seringkali banyak temuan/ kasus fraud yang terdeteksi dan terungkap. Sedangkan untuk penerapan Probity Audit dinilai cukup optimal, karena dalam pelaksanaannya pun masih belum menyeluruh dan konsisten dilakukan pada proses pengadaan barang/jasa pemerintah.

\subsubsection{Analisis Penerapan Audit Investigatif untuk Pengungkapan (Represif) Fraud dalam Pengelolaan Keuangan Daerah}

Penugasan bidang Investigasi Perwakilan BPKP Provinsi Sulawesi Utara pada Pemerintah Daerah di Sulawesi Utara baru dilakukan atas permintaan Instansi Penyidik (aparat penegak hukum) baik penugasan audit investigatif, audit dalam rangka penghitungan kerugian keuangan negara, maupun pemberian keterangan ahli. Dengan kata lain, penugasan bidang Investigasi pada Perwakilan BPKP Provinsi Sulawesi Utara belum dilakukan secara menyeluruh dan mandiri berdasarkan kewenangan sesuai ketentuan perundang-undangan.

Hasil analisa mengemukakan bahwa penerapan audit investigatif terhadap penanganan (represif) fraud dalam pengelolaan keuangan daerah melalui penugasan Audit Investigatif, audit dalam rangka Penghitungan Kerugian Keuangan Negara, dan Pemberian Keterangan Ahli adalah metode yang aplikatif dari audit investigatif berdasarkan teori maupun prakteknya sesuai juga dengan peraturan perundangan yang ada, berfungsi efektif sesuai dengan sasarannya untuk upaya represif atas fraud yang terungkap, sekaligus bisa bersifat preventif dalam konteks pemberian efek jera kepada pelaku fraud.

Dalam penerapan maupun pelaksanaannya, penugasan audit Investigatif, audit dalam rangka Penghitungan Kerugian Keuangan Negara, dan Pemberian Keterangan Ahli sudah dapat dikatakan optimal didasarkan pada target kinerja dan capaian dari bidang Investigasi, dengan laporan-laporan hasil audit investigasi, hasil audit dalam rangka Penghitungan Kerugian Keuangan Negara, dan Pemberian Keterangan Ahli sebagai alat evaluasinya terhadap jumlah kasus fraud yang terungkap baik yang jadi temuan maupun berdasarkan permintaan dari Aparat Penegak Hukum. Namun tetap perlu dibenahi dan dikembangkan baik secara internal maupun secara eksternal seperti yang sudah dijelaskan diatas. Secara ringkas, hasil analisis penerapan Audit Investigatif terhadap upaya penanganan fraud dalam Pengelolaan Keuangan Daerah.

Hasil analisis penerapan Akuntansi Forensik dan Audit Investigatif yang aplikatif dan berfungsi efektif terhadap pencegahan (preventif), pendeteksian (detektif), dan penanganan (represif) fraud dalam pengelolaan keuangan daerah dituangkan dalam bentuk chart seperti yang terlihat pada Gambar 5.1. 


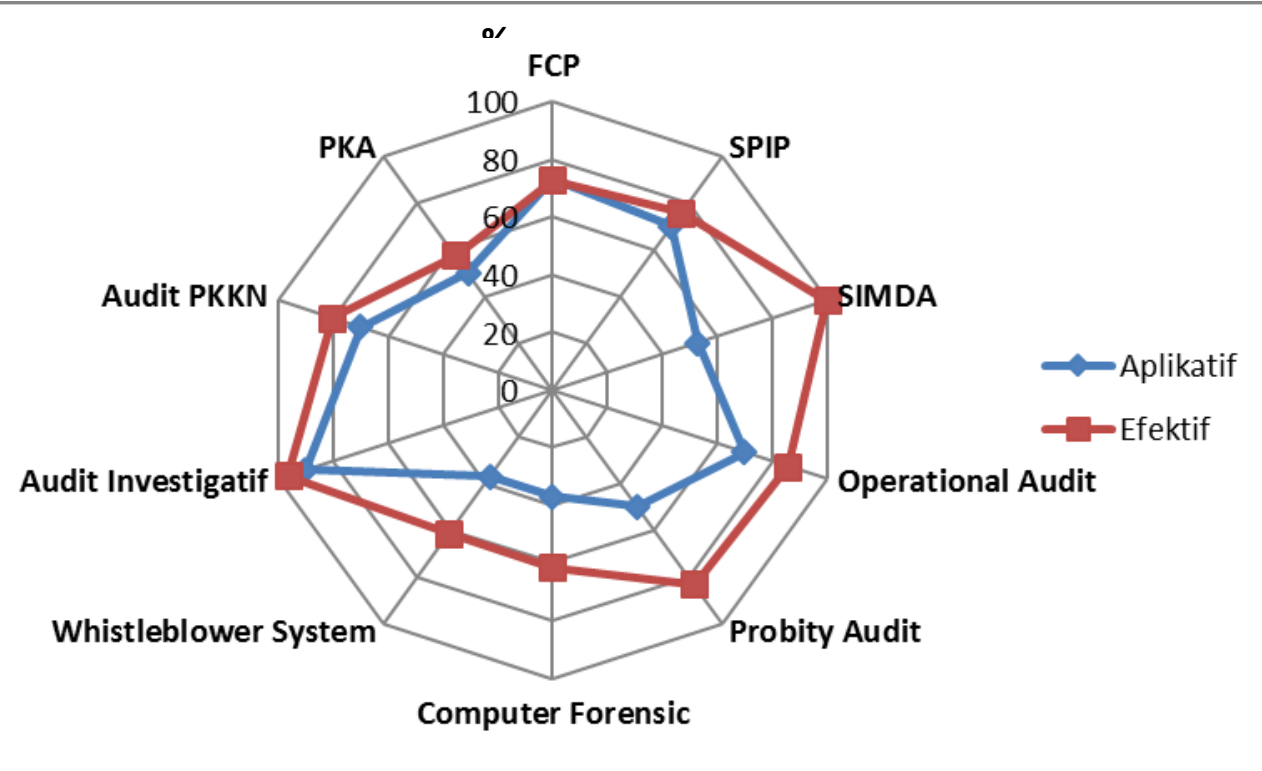

Sumber : data primer - hasil olahan.

Gambar 5.1 Chart Jaring Laba-laba Penerapan Aplikasi dan Keefektifan AFAI sebagai Preventif, Detektif \& Represif Tools Terhadap Pencegahan \& Pengungkapan Fraud Dalam Pengelolaan Keuangan Daerah di Sulawesi Utara

\subsection{Kesimpulan}

\section{KESIMPULAN DAN SARAN}

Berdasarkan hasil penelitian dan analisis pembahasan pada Bab sebelumnya, maka dapat ditarik kesimpulan atas penelitian ini, sebagai berikut.

1. Penerapan Akuntansi forensik terhadap pencegahan (preventif) fraud dalam pengelolaan keuangan daerah di Sulawesi Utara oleh Perwakilan BPKP Provinsi Sulawesi Utara dengan menggunakan tools-tools (sistem) pencegahan sebagai berikut :

a. Fraud Control Plan (FCP)

b. Sistem Pengendalian Intern Pemerintah (SPIP)

c. Sistem Informasi Manajemen Daerah (SIMDA)

Sistem-sistem pengendalian tersebut secara aplikasi merupakan sistem pencegahan terhadap fraud dan berfungsi efektif sebagai preventif tools terhadap fraud dalam pengelolaan keuangan daerah. Dalam pelaksanaannya FCP masih belum optimal oleh karena belum 'membumi-nya' FCP ini, dipengaruhi juga oleh kurangnya respon maupun komitmen dari Pemerintah Daerah. SPIP dalam pelaksanaannya sudah cukup optimal, upaya-upaya yang telah dilakukan seperti sosialisasi, bimbingan dan konsultasi, diklat maupun pedoman-pedoman yang telah dibentuk dan dijabarkan di Pemerintah Daerah dalam format Peraturan Kepala Daerah serta pembentukan Satgas SPIP. Sedangkan SIMDA sudah diterapkan dengan optimal dan seluruh Pemerintah Daerah di Sulawesi Utara khususnya sudah menggunakan aplikasi ini dengan berbagai keunggulannya.

2. Penerapan Akuntansi forensik terhadap pendeteksian (detektif) fraud dalam pengelolaan keuangan daerah di Sulawesi Utara oleh Perwakilan BPKP Provinsi Sulawesi Utara dengan melakukan kegiatan (metode) pendeteksian melalui :

a. Audit Operasional (Operational Audit)

b. Audit Pengadaan Barang dan Jasa (Probity Audit)

c. Audit Computer Forensic (EDP Audit)

d. Layanan Pengaduan (Whistleblower System)

Kegiatan-kegiatan tersebut adalah aplikatif dan berfungsi efektif dalam mendeteksi berbagai kecurangan (fraud) yang terjadi dalam pengelolaan keuangan daerah melalui metode 
pengawasan rutin (reviu) atas operasional organisasi, reviu secara real time atas pengadaan barang/jasa, dukungan keahlian dan teknologi IT, serta dalam bentuk pengaduan baik secara internal maupun eksternal organisasi. Khusus untuk Computer Forensic dan Whistleblower system belum diterapkan secara optimal karena metode ini masih dapat dikatakan baru dan sedang ada dalam pengembangan.

3. Penerapan Audit Investigatif terhadap penanganan (represif) fraud dalam pengelolaan keuangan daerah di Sulawesi Utara oleh Perwakilan BPKP Provinsi Sulawesi Utara dengan melakukan kegiatan penugasan di Bidang Investigasi meliputi :
a. Audit Investigatif
b. Audit Dalam Rangka Penghitungan Kerugian Keuangan Negara
c. Pemberian Keterangan Ahli

Penugasan di bidang Investigatif yang dilakukan adalah aplikatif dan berfungsi efektif dalam menangani kasus-kasus fraud yang terungkap dalam pengelolaan keuangan daerah, bahkan bukan hanya bersifat represif tetapi juga dapat bersifat preventif dalam konteks pemberian efek jera bagi pelaku fraud untuk tidak lagi melakukan tindakan-tindakan fraud. Dalam penerapannya sudah dilaksanakan secara optimal dengan ukuran capaian atas target kinerja dalam laporan hasil audit investigatif yang dilakukan, walaupun masih ada kekurangankekurangan seperti dalam pelaksanaan audit investigatif selama ini baru dilakukan atas dasar permintaan Aparat Penegak Hukum, belum secara proaktif dilakukan atas pengembangan hasil audit operasional maupun dari pengaduan sesuai dengan ketentuan peraturan.

Menutup kesimpulan, disadari bahwa pencegahan (preventif) fraud (korupsi) itu lebih efektif dari pada melakukan upaya represif, karena itu untuk memerangi fraud (korupsi) yang sistemik perlu ditangani dengan pola pencegahan yang sistematis dan handal pula dengan mengadopsi dan mengembangkan pendekatan ilmu akuntansi forensik dan audit investigatif yang dalam wujudnya menggunakan atribut-atribut yang spesifik yang merupakan pendalaman atau penguatan dari sistem tata kelola pemerintahan yang baik.

\subsection{Saran}

Pada dasarnya, formula sistem dan metode yang telah dirancang dan dibuat oleh pemerintah dalam upaya mencegah dan memberantas praktik-praktik fraud dalam pengelolaan keuangan negara khususnya pada Pemerintah Daerah adalah telah ideal pada tataran konsepnya disertai juga dengan penguatan dalam aspek hukum ketentuan perundang-undangan. Dari sisi teoritisnya pun sudah sesuai ditinjau dari ilmu akuntansi forensik dan audit investigatif terkait topik penelitian ini. Namun berdasarkan data-data dan fakta yang ada, seakan menjadi terbalik dengan harapannya, melihat perkembangan kasus fraud (korupsi) yang relatif tinggi dari tahun ke tahun dan menempatkan Pemerintah Daerah sebagai lembaga pelaku fraud tertinggi dibanding lembaga-lembaga yang lain.

Oleh karenanya, apabila melihat lebih jauh tentang penerapan maupun pelaksanaan dari sistem-sistem dan metode-metode yang ada, didapati bahwa umumnya sistem-sistem dan metodemetode tersebut masih belum dilakukan secara optimal dengan berbagai kendala dan hambatannya khususnya dalam hal pencegahan fraud yang menjadi fokus pemerintah seharusnya. Oleh karena itu, peneliti pada kesempatan ini menyarankan beberapa hal sebagai berikut :

1. Perwakilan BPKP selaku mentor APIP di Pemerintah Daerah, sebaiknya lebih mengintensifkan lagi pembangunan SPIP dan FCP di daerah secara konsisten dan merata. Secara khusus FCP yang masih banyak belum diketahui ('membumi') oleh ASN daerah dan belum banyak dipahami oleh APIP daerah, pejabat instansi, maupun pemimpin daerah.

2. BPKP perlu memperlengkapi dan menunjang kompetensi dan keahlian dari SDM auditorauditor yang ada khususnya di bidang Investigasi pada Perwakilan BPKP untuk menjawab tuntutan kemajuan teknologi informasi, yang membuat praktik-praktik fraud juga semakin beragam dan canggih, seperti sedang dikembangkannya praktik Computer Forensic yang sangat berguna untuk mengungkap fraud di lingkungan digital sekarang, disamping terus mengembangkan kemampuan di bidang akuntansi, auditing, hukum, kriminologi, IT, dan lainlain. Kegiatan diklat (training), workshop, dan sebagainya terkait peningkatan kompetensi perlu 
dipertimbangkan untuk lebih digiatkan dalam upaya pembangunan SDM yang lebih berkualitas.

3. BPKP sebaiknya mempertimbangkan untuk kebutuhan-kebutuhan dalam rangka optimalisasi kinerja organisasi meliputi pemerataan kuantitas SDM (jumlah personil) sesuai analisis beban kerja, peningkatan kapasitas SDM (diklat dan sertifikasi), anggaran yang memadai, peningkatan kesejahteraan auditor dengan basis kinerja, dan fasilitas-fasilitas (tools and equipment) penunjang dalam melakukan penugasan secara khusus di Perwakilan BPKP.

4. BPKP sebaiknya melakukan penugasan bidang Investigasi secara mandiri dan menyeluruh sesuai ketentuan dan peraturan yang ada, yang pada dasarnya telah memberikan kewenangan kepada BPKP untuk melaksanakannya secara proaktif, tentunya didukung oleh instrumen aturan-aturan teknis pelaksanaan (juknis/juklak) dari Pusat.

5. BPKP maupun Pemerintah Daerah harus lebih bersinergi lagi dalam membangun tools-tools (sistem dan metode) yang sudah ada dalam rangka pencegahan dan pemberantasan fraud. Peran APIP di daerah sebagai mitra kerja BPKP dalam mengawal pembangunan dan penyelenggaraan pemerintahan di daerah harus terus digiatkan dengan upaya peningkatan kapasitas APIP di daerah, melalui koordinasi dan komunikasi yang aktif, asistensi yang interaktif, edukasi dan sharing/transfer knowledge yang seharusnya bersifat saling melengkapi, dan berbagai pelatihan, sosialisasi, workshop yang terus dievaluasi secara berkesinambungan sehingga APIP daerah juga pada akhirnya dapat ditarik kapasitasnya bukan sekedar memberikan assurance tetapi menjadi consultant.

\section{DAFTAR PUSTAKA}

Albrecht, W. Steve, Albrecht, Chad O., Albrecht, Conan C., \& Zimbelman, Mark. F., 2011. Fraud Examination. 4th Edition. USA: South-Westem Cengage Learning.

Association of Certified Fraud Examiners, 2008. Report to Nation on Occupational Fraud \& Abuse. Texas : The Association of Certified Fraud Examiners, Inc.

Association of Certified Fraud Examiners, 2016. Fraud Examiners Manual (International Edition).

Texas: The Association of Certified Fraud Examiners, Inc.

Badan Pengawasan Keuangan dan Pembangunan, 2008. Fraud Auditing, Edisi kedua, BPKP, Jakarta.

Bologna \& Linquisdt, 1995. Fraud Auditing and Forensic Accounting: New Tolls and Techniques. New York, USA : John Wiley \& Sons, Inc.

Cressey, 1953. Other People Money, Study in the Social Psichology of Embezzlement. Montclain, JN: Patterson Smith.

Creswell, 2007. Qualitative Inquiry \& Research Design : Choosing Among Five Approaches. Thousand Oaks, $2^{\text {nd }}$ Edition, CA: Sage.

Crumbley, 2005. Forensic and Investigative Accounting. USA. CCH Group: ISBN 0808013653, 2005.

De Lorenzo, 1993. Forensic Accounting. In The Black Journal, Vol. 63, No. 2.

Fauzan, Purnamasari dan Gunawan, 2015. Pengaruh Akuntansi Forensik dan Audit Investigatif terhadap Pengungkapan Fraud (Studi Kasus pada Badan Pengawasan Keuangan dan Pembangunan Perwakilan Jawa Barat). Prosiding Akuntansi. ISSN: 2460-6561.

Handoyo, 2009. Pendidikan Anti Korupsi. Semarang: Widyakarya Press.

Hopwood, W. S. Leiner, J. J. \& Young, G. R. 2008. Forensic Accounting. New York, : McGraw Hill/ Irwin Companies.

Howard \& Sheetz, 2007. Forensic Accounting and Fraud Investigation for Non-Experts. New York, USA : John Wiley \& Sons, Inc.

Ikatan Akuntan Indonesia, 2001. Standar Profesional Akuntan Publik. IAI - Kompartemen Akuntan Publik, Jakarta. 
Ikatan Akuntan Indonesia, 2002. Standar Akuntansi Keuangan. IAI - Kompartemen Akuntan Publik, Jakarta.

Jumansyah, Dewi dan Tan, 2012. Akuntansi Forensik dan Prospeknya terhadap Penyelesaian Masalah-Masalah Hukum di Indonesia. Prosiding Seminar Nasional "Problematika Hukum dalam Implementasi Bisnis dan Investasi (Perspektif Multidisipliner)".

Lediastuti dan Subandijo. 2014. Audit Forensik terhadap Pengelolaan dan Pertanggungjawaban Keuangan Negara (Studi Kasus pada Badan Pemeriksa Keuangan RI). e-Journal Magister Akuntansi Trisakti, Vol. 01, No.1, Februari 2014.

Miqdad, 2008. Mengungkap Praktek Kecurangan (Fraud) pada Korporasi dan Organisasi Publik Melalui Audit Forensik. Jurnal Ilmu Ekonomi, Vol.3, No.2, Februari 2012.

Okoye and Gbegi, 2013. Forensic Accounting: A Tool for Fraud Detection and Prevention in the Public Sector. (A Study of Selected Ministries in Kogi State). International Journal of Academic Research in Business and Social Sciences. Vol.3, No.3, March 2013. ISSN: 2222-6990.

Santoso, 2011. Efisiensi dan Efektivitas Pengelolaan Keuangan Daerah di Kabupaten Ngawi. Tesis. Surakarta : FE-Universitas Sebelas Maret.

Shodiq, Carolina, dan Sambharakhresna. 2013. Persepsi Auditor Terhadap Penerapan Audit Forensik Dalam Mendeteksi Kecurangan Penyajian Laporan Keuangan (Survey pada Kantor Perwakilan BPKP Jawa Timur). JAFFA - Vol. 01, No.2, Oktober 2013.

Sihombing, 2014. Analisis Fraud Diamond Dalam Mendeteksi Financial Statement Fraud : Studi Empiris pada Perusahaan Manufaktur yang terdaftar di Bursa Efek Indonesia (BEI) Tahun 2010-2012. Diponegoro Journal of Accounting - Vol.03, No.2, 2014.

Soepardi, 2010. Peranan BPKP dalam Penanganan Kasus Berindikasi Korupsi Pengadaan Jasa Konsultansi Instansi Pemerintah. Paper Seminar. Jakarta: Juni 2010.

Sugiyono, 2005. Metode Penelitian Kualitatif. Bandung: Alfabeta.

Sugiyono, 2014. Metode Penelitian Kuantitatif, Kualitatif dan R\&D. Bandung: Alfabeta.

Swarna, 2012. Penerapan Akuntansi Forensik dan Audit Investigasi dalam Mendeteksi Fraud di Lingkungan Digital. Medan : Fakultas Ekonomi-Universitas Sumatera Utara.

Tuanakotta, 2012. Akuntansi Forensik dan Audit Investigatif. Jakarta: Edisi 2, Salemba Empat.

Tuanakotta, 2009. Menghitung Kerugian Keuangan Negara dalam Tindak Pidana Korupsi. Jakarta: Salemba Empat.

Tunggal, 2011. Audit Kecurangan dan Akuntansi Forensik (Tanya-Jawab \& Kasus). Jakarta: Harvarindo.

Tunggal, 2012. Forensic \& Investigatif Accounting - Pendekatan Kasus. Jakarta: Harvarindo.

Wiratmaja, 2010. Akuntansi Forensik Dalam Upaya Pemberantasan Tindak Pidana Korupsi. Jurnal Akuntansi. Bali : Fakultas Ekonomi - Universitas Udayana.

Zimbelman, Mark. F., Albrecht, Conan C., Albrecht, W. Steve, \& Albrecht, Chad O., 2014. Akuntansi Forensik (Forensik Accounting). Edisi Keempat. Jakarta : Salemba Empat, Cengage Learning Asia Pte Ltd. 